DOI: https://doi.org/10.47405/mjssh.v5i4.398

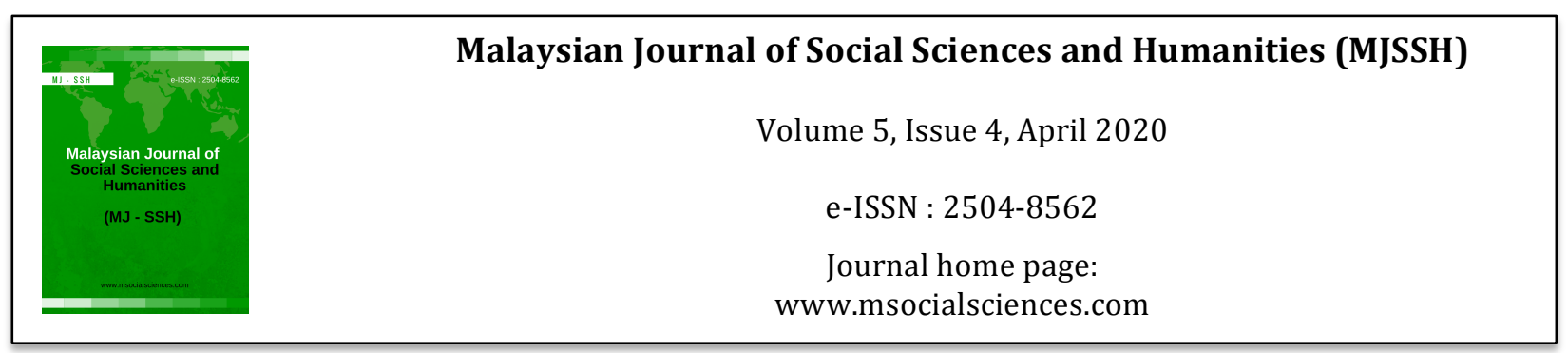

\title{
A Study on Customer Perception on San Francisco Coffee in KL Gateway Mall
}

\author{
Adwa Qamarina Binti Mohd Yusof'1, Amira Alya Binti Razali'1, Cahya Medina Binti Mohd Rizal' ${ }^{1}$, Ho \\ Ruoh Jyu1, Jegan Motalaiyar Mahendran', Kelvin Tan Wei Hoong1, Mohamad Hafiz Bin Mohd \\ Kamaruz Zaman1, Vasudevan Naidu Kanan', Isai Amutan Krishnan², Kausalya Muthutamilselvan ${ }^{3}$ \\ 1University Malaya Centre for Continuing Education (UMCCed), University of Malaya (UM) \\ ${ }^{2}$ Faculty of Languages and Linguistics, University of Malaya (UM) \\ ${ }^{3}$ Lorong 2A/5 Taman Mutiara, Sg. Kob Karangan, Kulim, Kedah
}

Correspondence: Isai Amutan Krishnan (amuthan.isai@gmail.com)

\begin{abstract}
This research is an attempt to identify the customer perception on San Francisco Coffee in KL Gateway Mall. Customer's assumptions on their preferred shop are very important because it could affect their loyalty towards the shop as well as its survival in the market. This paper surveys the customers' perception of San Francisco Coffee in Kl Gateway Mall using a structured questionnaire. There are two sections of this study: Section A involve the demographic information, while Section B focus on the independent variables. A total of 100 self-administered survey questionnaires was distributed for thie present study and the same amount was expected to be collected back. There are four variables included in the questionnaire to determine the customer's perception towards the coffee shop: (i) price, (ii) service quality, (iii) brand image, and (iv) cleanliness. Furthermore, five Likert-scale were employed to analyse the data needed for the present study. Additionally, the study consist of four research objectives, which are to evaluate the customer response, identify the problems they faced, discover the most effective strategy and techniques, as well as evaluate the satisfaction level of the customers. The predicted outcome from the study result shows that all the variables have an impact on customer's satisfaction as it defined how the shop manage to satisfy its customers based on the variables. However, the current study only focuses on customers of San Francisco Coffee shop in specific area (KL Gateway Mall). As such, future research can develop a larger sample size in order to enhance the accuracy and reliability. Also, other variables (taste, ambiance and environment) that affect customer's satisfaction can be included in future research. There are only several past studies that identify the customer's perception in coffee shop.
\end{abstract}

Keywords: San Francisco Coffee, customer perception, service quality

\section{Introduction}

San Francisco Coffee is ranks second place as the best coffee chain in Malaysia. The company operates as coffee stores in Malaysia, and includes in their services drinks, pastries and cakes. They also offer delivery and catering services as well. These shops are located in many area of Malaysia, such as Kuala Lumpur and Subang Jaya, but the present research location is KL Gateway Mall. The purpose of chosen San Francisco Coffee at Kl Gateway Mall is because of its popular request by their loyal customers. The aims of the current study is to investigate the customer view, opinion, and perception towards San Francisco Coffee. 
Customer satisfaction refers to consumer's evaluation of products and services performance in fulfilling their expectation (Yi, 1991). According to Goi (2013), the coffee drinking culture has been present in Malaysia for many years, especially the culture of drinking local coffee every day, while the culture of drinking western trend coffee exists due to the influence of foreign residents who reside and work in Malaysia in 2012. Researchers indicated that, customers will select restaurants that meet their standards for quality and value, thus restaurateurs who ignore this will see their customer traffic decline as guests support competing restaurants (Stevens, Knutson et al. 1995). Given that there are many competitors who provide similar products or services in a particular industry, loyal customers are difficult to maintain as they are easy to find substitutes in a competitive market. Previously, a lot of studies related to customer satisfaction has been conducted. However, very few of these studies measure the relationship between customer satisfaction and the four variables (cleanliness, customer service, price and brand image). Based on the important role these four variables plays in determining the customer's satisfaction towards San Francisco Coffee, hence the reason for the present study.

According to previous literatures, there are few reviews from tripadvisor.com that focus on customer service, thus its study has been seen a bit lower than average (Prisca0913, 2018). RoeCikL (2018), stated that the cashier was rude to her, saying you are not allowed to order Cappuccino and only black. Also, they are still in doubt of the shop's birthday promotion whether it is still available or not.

In terms of the cleanliness of the shop on tripadvisor.com, Iceman0911 (2015), stated that the coffee shop smells like a dead rat. Other than that, the customers also experienced issue about the bottle cap dropping inside the coffee cup unintentionally. Also, the coffee shops do not have their own brand of product, meaning that they use product from outside, such as Goodday product as milk to make their drinks.

Last but not the least, with regards to the problem of coffee price. Based on the verbal perception of customers on San Francisco Coffee shop, it is a bit pricy compared to what are expected to be received. This means that the drinks is not the same quantity with the price. Indeed, companies which fail to provide good services will fail to restore customer satisfaction and consequently enhance customer loyalty (Chu, 2007). Therefore, the purpose of the stud is to evaluate the customer response, identify the problems that occur, discover the most effective strategy and techniques to maintain loyalty of the customer, and ensure that the products are selling as well as to evaluate the satisfaction level of customer towards San Francisco Coffee.

\section{Definitions}

\section{Price}

Price is a non-product information and purchase intention of a buyer which include perceived price, perceived quality and perceived value of intervention variables that have been empirically tested (Chang \& Albert, 1994). It is something that has given up or sacrificed in order to obtain a product (Ahtola \& Olli, 1984).

\section{Service Quality}

Parasuraman, Zeithamal and Berry (1985), stated that the quality of service is the "expectation" before the consumer received the service and the "perception" after the customer, received the service. This is because if the quality of service is equal to expectations and meet the consumer satisfaction, it will have a significant impact on consumer perception.

\section{Brand Image}

Brand image is a set of associations that are usually organized in some meaningful way (Aeker, 1992). It can be defined as the image of any particular product that is set to the mind of any individual (Aeker, 1992). 


\section{Cleanliness of shop}

Cleanliness is an important aspect of the restaurant industry (Seung, 2012). Nowadays, the problems of the restaurant cleanliness and food safety are getting more attention from the viewpoint of management and consumers (Seung, 2012).

\section{Past Studies}

Seung (2012), conducted a study on Customer Perception of Restaurant Cleanliness: A Cross Cultural Study to investigate the customers' perceptions of restaurant cleanliness. The result show that there is a significant difference in the perception of Westerns and Asians regarding a restaurant's cleanliness. Also, the study was condutced with two focus group, which is Western participants and Asian participants respectively.

Yeu and Leu (2014) conducted a study on the Recruitment of Migrant Workers in the Food Servic Industry of Malaysia. A Case Study of Old Town White Coffee and Papa Rich Kopitiam. Their research aims to examine the factors which led to the recruitment of migrant workers in Malaysian café segment of food service industry. They employed quantitative methods in order to quantify and interpret the results of their study, where the targeted population was the managers of Old Town White Coffee and Papa Rich Kopitiam franchise outlets in Malaysia. They found that both of the franchise coffee shop brands which is Old Town White Coffee and Papa Rich Kopitiam employed more migrant workers than local ones.

Conversely, Cheng and Leow (2014) conducted a study on Factors Influencing Purchase Intention of Starbucks. Their major objective was to find out the factors affecting the purchase intention of Starbucks so as to remain its customers and increase sales as well. The result show that there is a positive relationship between price, service quality, brand image and Corporate Social Responsibility (CSR) as well as purchase intention. The targeted population in thier study was customers who visiting Starbucks at Klang Valley areas, amd similarly the questionnaire were distributed among Klang Valley.

Furthermore, Lim, Ooi and Tan(2014) conducted a Study on Newly Opened Cafes and Restaurants in Penang. Their research determines the impact of service quality and price fairness on customer loyalty in food and beverage industry of Penang. The result show that there is a negative relationship between tangibles and customer loyalty. It was also considered as the weakest among all the independent variables. The targeted population is customers of the newly opened cafés and restaurants in Penang. The data employed for in the study was collected through the questionnaire distributed to the customer.

More so, Amir Azahari Zainol, Kisun, Siti Nor Izzaty Norashikin and Zurinawati Mohi (2015) carried out a study on Student Satisfaction towards Caffe Giunto (2015). Their purpose was to investigate the relationship between the service quality dimensions towards student satisfaction in Caffe Giunto, where 170 students who dined at Caffe Giunto were been surveyed. The results show that there is a significant relationship between service quality and student satisfaction in Caffe Giunto. The data employed for the study was collected through a personal management questionnaire.

Also, Zul Asmi (2015) conducted a study on Factors Influencing Customer Satisfaction and How It Results in Customer Loyalty - Evidence from Fast food Restaurants. The study aim was to investigate the influences of service quality and food quality towards customer satisfaction as well as the impact of customer satisfaction on customer loyalty in Fast Food Restaurants. The study targeted respondents ranging from 19 years old to 22 years old of undergraduate students of the Universiti Sains Malaysia (USM). The quantitative method was applied to the research and the instrument used to collect data was questionnaire which was distributed to 25 respondents. The result shows that service quality and food quality does influence and increase customer satisfaction. However, the findings also showed that customer satisfaction does not significantly influence customer loyalty. 
Kumar, Loo, Khor and Mohammad Azam Din (2016) also conducted a Case Study on Starbucks Influencing Malaysian Coffee Drinkers and Their Lifestyles, which purpose is to investigate Starbucks influence towards Malaysian and their lifestyles. Their research results recommends that Starbucks did portray lifestyles of middle class of Malaysian and the ambience of café is one of the attractions of its customers. The methodology used in the study comprises literature survey, consumer surveys, hypothesis development and verification by surveys results analysis.

In another vein, Godiva (2017) conducted a study on Factors Positively Affecting Purchase Behavior of Coffee Consumers in Wattana District of Bangkok. The study objective is to determine the positive influence of sensory appeal, packaging along with branding, service quality, environmental protection, perceived heath concerns, perceived hedonic value, and subjective norm towards consumer purchase behaviour of coffee consumer in Wattana District of Bangkok. There are 210 survey respondents distributed to coffee consumers at coffee vis a vis bakery shops, convenience stores, fast food stores and street coffee kiosk at Thonglor, Ekkamai, and Prakhanong areas of Watthana District of Bangkok. These variables are thought to have relationships and impact on the behaviour of coffee consumers of Wattana District, Bangkok.

Another research by Noorliza Zainol and Farina Tazijan (2018) was conducted on a study of Service Quality Measurement in Kopitiam Seberang Jaya, Pulau Pinang. Their research aim to identify the customer perception towards the service delivery and their revisit intention. The result show that majority of the respondents agreed on the service delivery of kopitiam is meeting their expectation and show their intention to revisit the kopitiam. The targeted population was customer who visited Kopitiam in Seberang Jaya, Pulau Pinang. The study data involve the development the dua collected through the questionnaire by distributing to the customer.

A research was also carried out by Azdel Abdul Aziz \& Muhamad Saufiyudin Oma (2018) on the Relationship between Brand Personality and Customer Satisfaction in Local Coffee Shop. The objective for their research are to examine the relationship between brand personality and customer satisfaction as well as to determine which brand attribution is highly influencing customer's satisfaction. Finding from the study suggested that brand personality correlate with customers' satisfaction, but ruggedness attribute is the most influence for the customer satisfaction. The study data was collected through surveyed questionnaire and completed by 400 respondents who had experiences in dining at the Local Premium Coffee Shops of Klang Valley, Selangor Malaysia.

Mohd Salehuddin Mohd Zahari (2010), in the article of restaurant brand image attributions, customer preferences and purchase decision, main objective was to assessing restaurant brand image attributions, customer preferences and the extent of its influence on customer purchase decision. Their study sampling was targeted on price, location, convenience and employee's related attributions. Questionnaire were used in the studies to find out the brand image attributions, customer preferences and purchase decision. The result shows significant contribution insights and impact of not only to the existing casual dining restaurant operators ut also to those individuals or company who intend to venture into this business.

Based on the research done by Prabhakar (2010), in the article of service quality (servqual) and its effect on customer satisfaction in retailing, where their objective focus on the uses servqual to analyze the gap between perceptions and expectations of the customer, concerning with the service at retail units in the South Indian state of Andhra Pradesh. The sampling were targeted using the survey crosssectional applied to 369 respondents. Questionnaire were also used in their research to meet the objective of the uses servqual to analyze the gap between perceptions and expectations of the customer, concerning with the service at retail units of the South Indian state of Andhra Pradesh. Findings of this empirical research reiterate the point of view that Service Quality dimensions are crucial for customer satisfaction in retailing a burgeoning sector with high growth potential and opportunities of fast growing economies like India's.

$\mathrm{Ng}$ (2016) also study on factors affecting customer loyalty on cafe in Ipoh: a mediation effect of customer satisfaction. The aim of the study was on the importance of the service quality and price 
fairness affecting the customer satisfaction and loyalty on domestic cafe in Ipoh. The sample were distributed to 250 respondents who visit the cafes in selected 5 cafes in Ipoh, through the used of questionnaire as instrument of the research. The result revealed that empathy, reliability, tangible and price fairness have positive influence on customer satisfaction and loyalty, vice versa effect on responsiveness and assurance dimension.

Based on research done by Arma Mohd Faizal Abu Bakar (2017), he stated that the aim for his research were the University students' perception on the fast food industry service quality in Terengganu. The study data was collected through the questionnare and distributed towards 200 respondents of the university students. The result shows that majority of the university students perceived fast food restaurants in Terengganu to be of a high quality.

Yousef Keshavarz (2016), studies on the influence of service quality on restaurants' customer loyalty. The study investigates the customers' expectation and perceptions of service quality delivered by restaurants in Shiraz and its effect on customers' satisfaction and loyalty. The sampling method involve 450 customers of the restaurants located in all nine districts of Shiraz and the data was collected from the respondents by means of a questionnaire. The result shows that the customers' expectation yielded a significant effect on the customer's perceived quality and loyalty.

Based on Cheng and Leow (2014) and Loo \& Khor (2016), the present study beleieved that there are many efforts that has been carried out on Starbucks but yet no research attempt on San Francisco Coffee considering its branches and loyal customers base. Therefore, the current resaerch try to attempt a study on San Francisco Coffee located at KL Gateway Mall. Other than that, the study on Cheng \& Leow (2014) and Loo \& Khor (2016) are more focus on the buying intention influencing by factors but the present study is more focus on customer perception.

\section{Methodology}

Figure 1 shows that there are four parts in the independent variable, which are price, service quality, brand image and cleanliness. As such, joining this four parts will meet the present research objectives, which is customer satisfaction under the dependent variable.

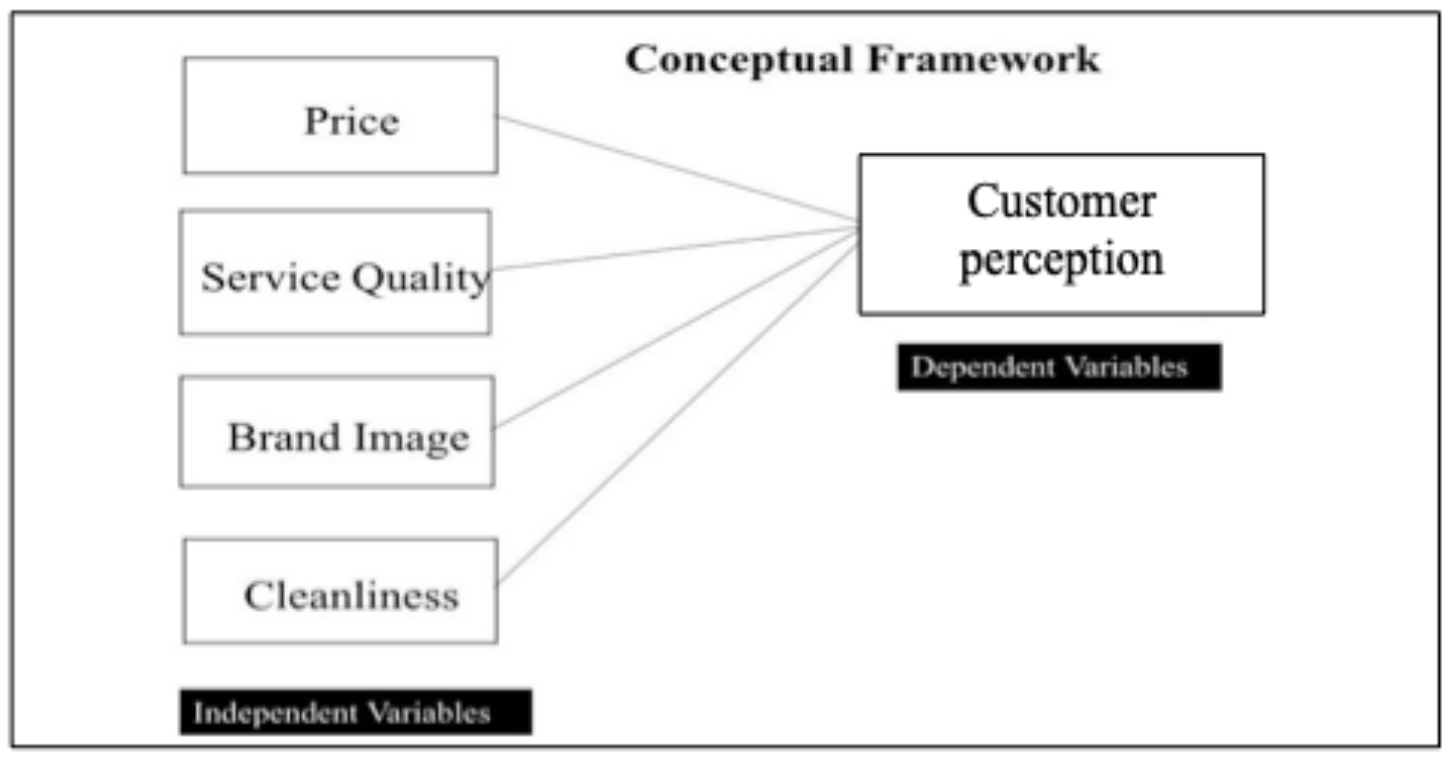

Figure 1. Conceptual Framework Sources: Cheng (2014) and Yoo (2012) 


\section{Research Approach}

Table1 shows the setting, sampling and instrument for the present research. The questionnaire for this study was distributed to the customers of San Francisco KL Gateway, and the non-probability sample was als employed consisting of 100 volunteer respondent. It consists of 2 part (A and B), where the early consist of demographic information, while the later is about the customer perception on San Francisco KL Gateway, comprising of price, service quality, brand image as well as the cleanliness. Additionally, Part B was measured by a five- point Likert scale rating from 1 (strongly disagree) to 5 (strongly agree).

Table 1: Setting or Location, Sampling and Instruments

\begin{tabular}{|c|c|c|}
\hline 1. SETTING & 2. SAMPLING & 3. INSTRUMENT \\
\hline $\begin{array}{l}\text { Organization: San } \\
\text { Francisco Coffee (SF) }\end{array}$ & $\begin{array}{l}\text { Number of participant: } \\
100 \text { customer of San } \\
\text { Francisco Coffee }\end{array}$ & $\begin{array}{l}\text { Survey : Questionnaire } \\
\text { (A set of question that } \\
\text { consist of } 2 \text { section) }\end{array}$ \\
\hline $\begin{array}{l}\text { Location: KL Gateway, } \\
\text { Kuala Lumpur } \\
\text { Nature of business: }\end{array}$ & $\begin{array}{l}\text { Average spending : } \\
\text { Below RM50- RM } 100 \\
\text { above }\end{array}$ & $\begin{array}{l}\text { - Section A: } \\
\text { Demographic } \\
\text { Information }\end{array}$ \\
\hline Food and beverages & $\begin{array}{l}\text { Age: } 18-65 \text { years old } \\
\text { Gender: Male, Female } \\
\text { Race: Mixed Races } \\
\text { (Malay, Chinese and } \\
\text { Indian) }\end{array}$ & $\begin{array}{l}\text { Section B: Price, } \\
\text { Service } \\
\text { Quality, Brand } \\
\text { Image and } \\
\text { Cleanliness }\end{array}$ \\
\hline
\end{tabular}

\section{Data Collection and Data Analysis Procedures}

The first step taken in the present study involve getting the permission letter from the UMCCed management to conduct a survey. Thereafter, the data collection was carried out using questionnaire that is adapted from previous study by Cheng (2014) and Seung (2012). The five likert-scales were applied in the questionnaire as well and lastly, the result was interpreted into graphs.

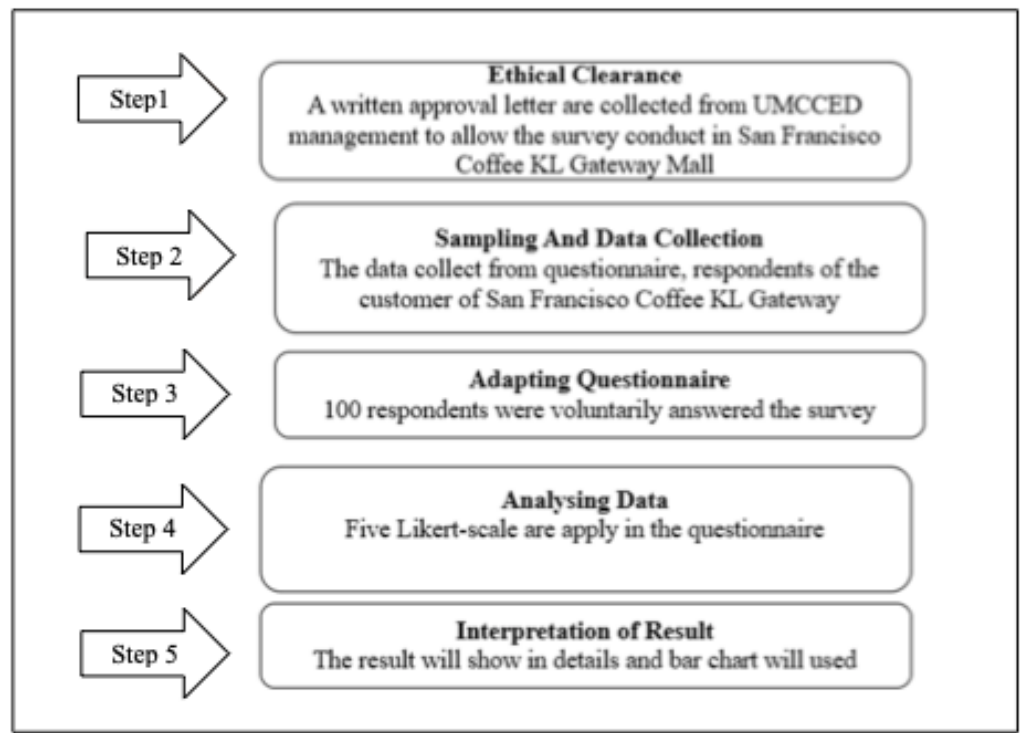

Figure 2: Data Collection and Analysis Procedures 


\section{Pilot Test}

Pilot test is a small-scale research that compiles data from respondents with similar characteristic that can be use in a study (Zikmund et al., 2010). Also, it provides researches the opportunity to find out potential problems that may occur to respondent while answering the questionnaire and make adjustment (Pratt \& Gau, 2008). It is conducted before the actual survey to ensure the accuracy and reliability of the questionnaire (Saunders et al., 2010). For the present study, it is being distributed face to face to respondent to allow easier collection of feedback. A total of 10 copies of pilot test sample was distributed to consumers who have consumed customer San Francisco Coffee in KL Gateway Mall before the actual survey was conducted. Table 3.2 shows the Cronbach's Alpha value of the independent variables. The pilot testing indicated a good number of reliability of 0.87 as utilized in SPSS.

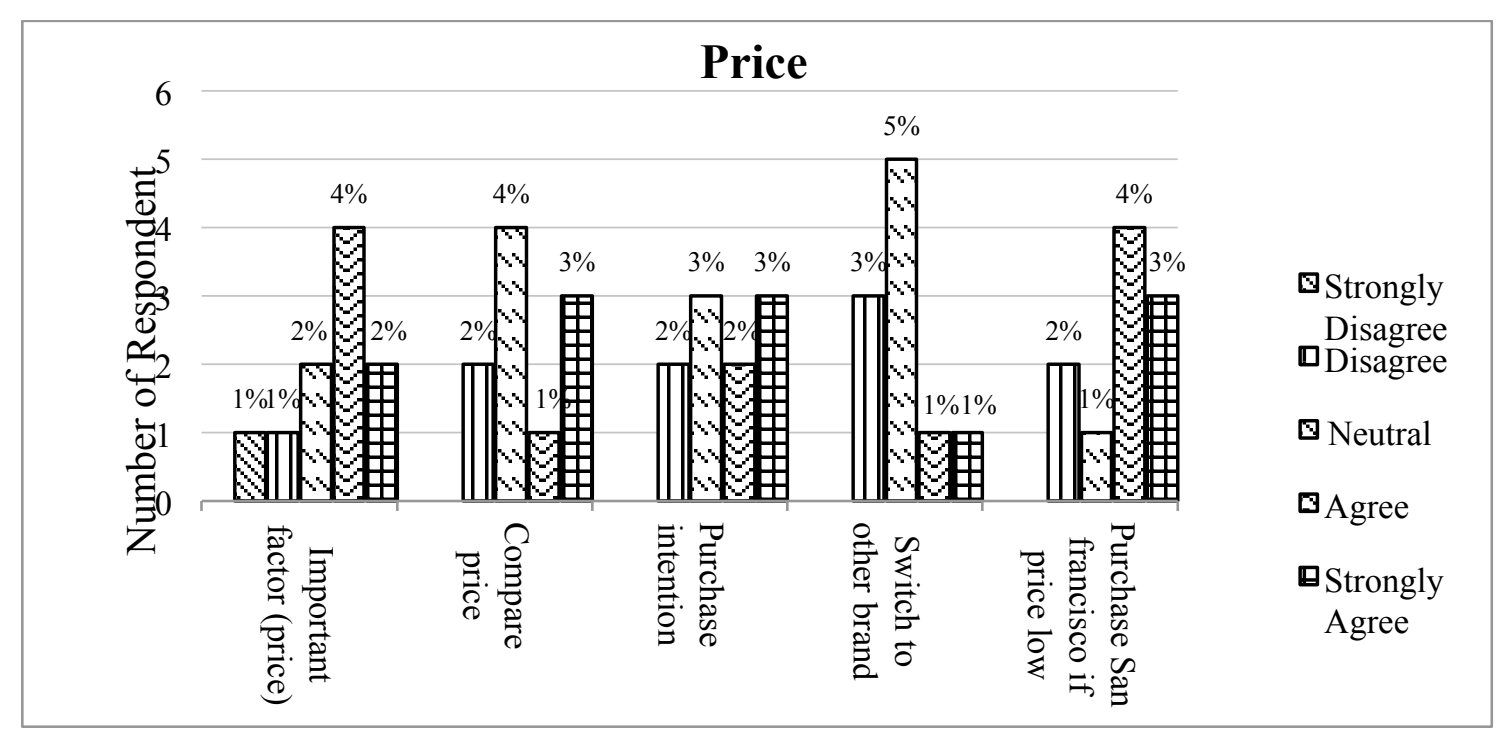

Figure 3: Data Collection of Pilot Test for Price

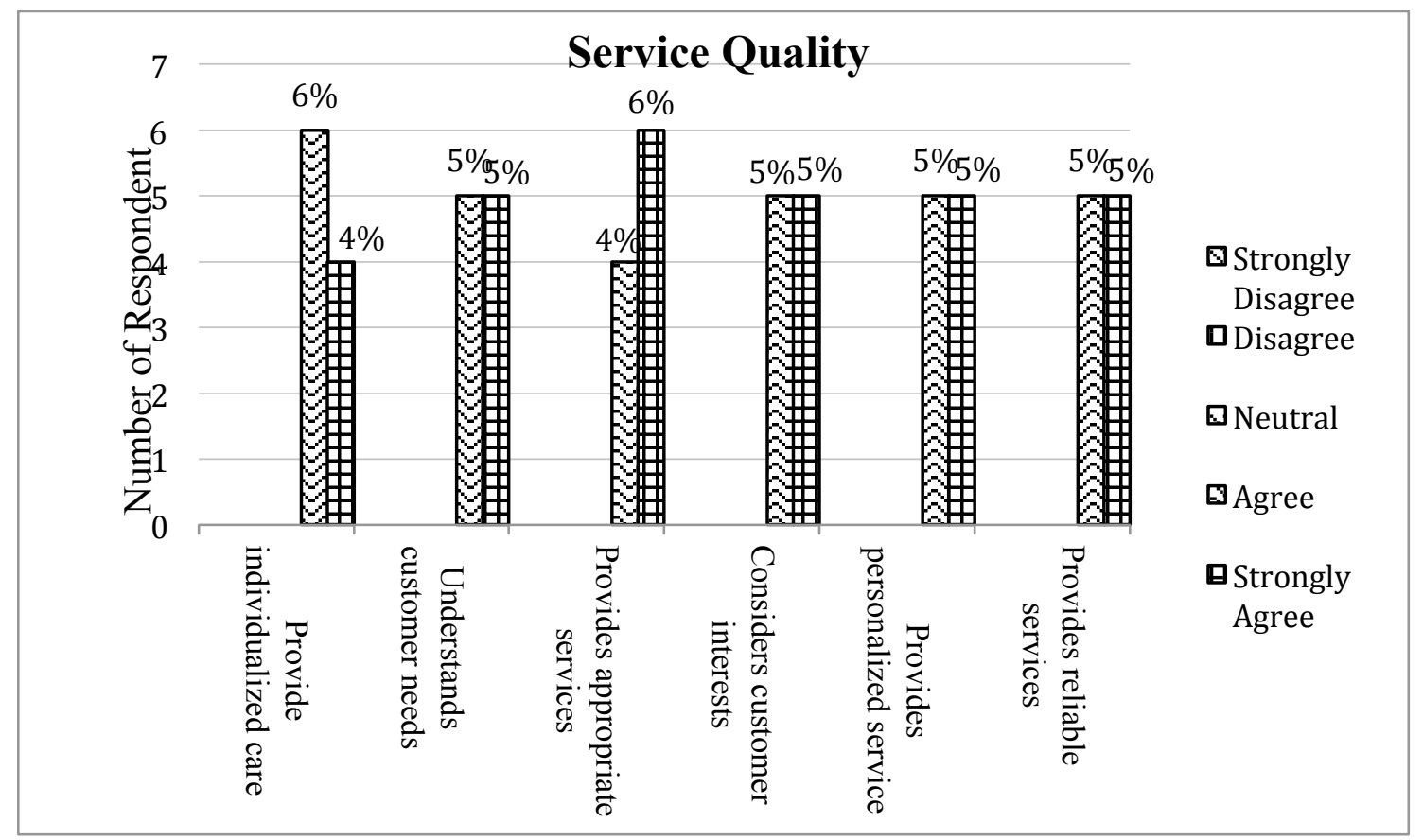

Figure 4. Data Collection of Pilot Test for Service Quality 
DOI: https://doi.org/10.47405/mjssh.v5i4.398

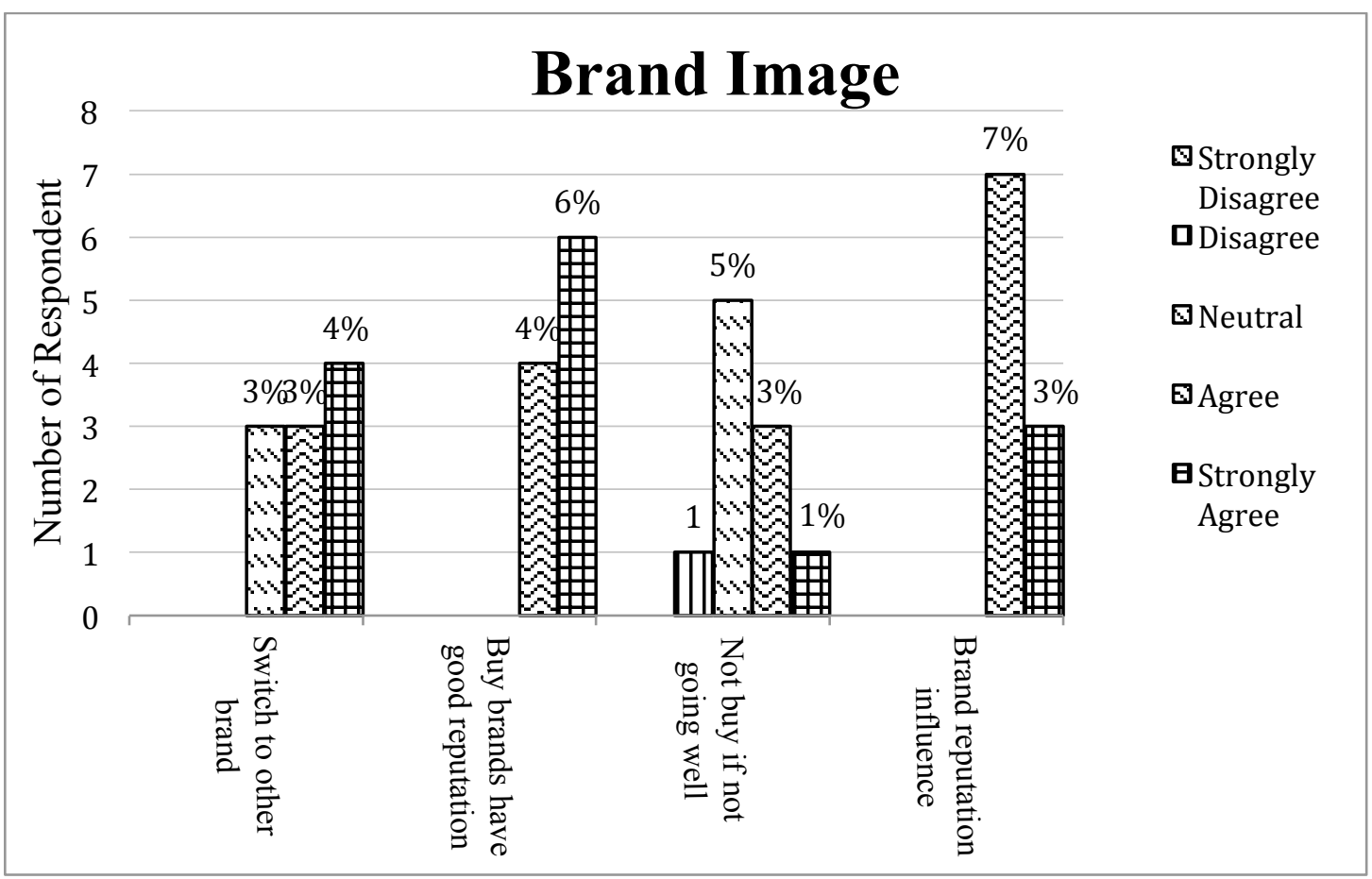

Figure 5. Data Collection of Pilot Test for Brand Image

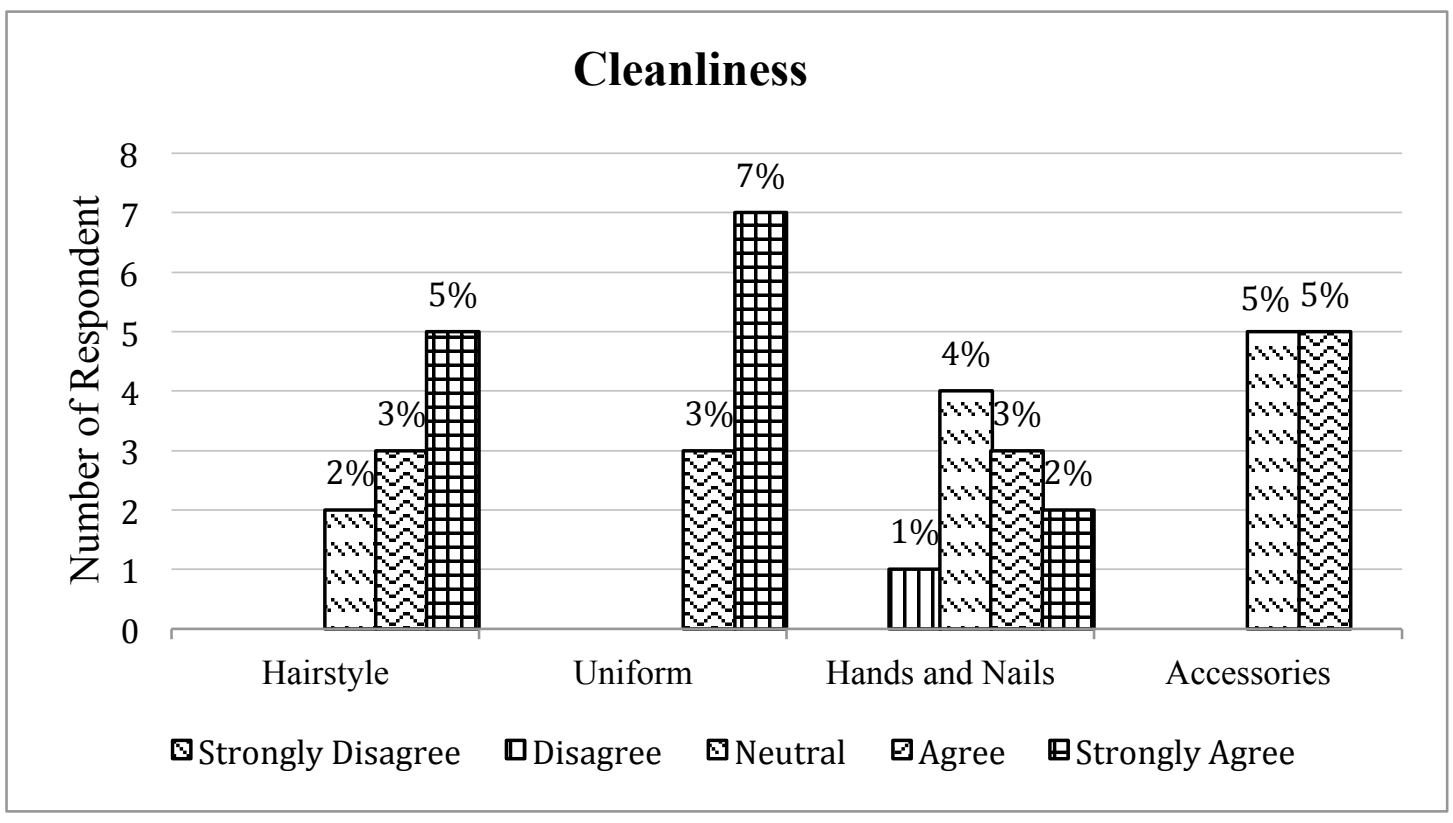

Figure 6. Data Collection of Pilot Test for Cleanliness

Table 2: Reliability and Validity

\begin{tabular}{llc}
\hline No & Variable & Cronbach's Alpha \\
\hline 1 & price & 0.711 \\
2 & Service quality & 0.855 \\
3 & Brand image & 0.701 \\
4 & Cleanliness & 0.814 \\
\hline
\end{tabular}




\section{Analysis and Discussion}

The section describes in detail the outcome or results of a research based on the data analysis collected from the survey. There are three parts in this section consisting of analysis, discussion and closing remarks. Firstly, the analysis describe the result of data, specifically into the graph. Secondly, it discusses about the data that obtained from the survey. Lastly, the closing remarks is the closing paragraph in a formal report as an important section that leaves a final impression on the reader. The closing should not only analyse the report in a clear and concise manner, but also state the conclusion one have come to base the information from the report. For the present study, the survey questionnaires were distributed randomly through the non-probability method. A total of 100 questionnaires were distributed and used for the present resrach, while the five Likert-scale rating was employed for the questions.

\section{Demographic profile}

There are 4 questions in section A that represent the demographic profile of the respondents. Based on the questionnaires collected, there are total of 100 respondents, with 53 of the respondents being male and 47 female respectively.

Figure 8 shows that majority of the customers that drink coffee at San Francisco Coffee at the age of 18 to 25 years old consists of $39 \%$ of the total respondents. Others are $34 \%$ from age 26 to 33 years old, while $21 \%$ are from the age of 34 to 41 years old. Furthermore, $4 \%$ of the total respondent are at the age of 42 to 49 years old. Lastly, $1 \%$ of the total respondent are from the age of 50 to 57 and 58 to 65 years old respectively.

Based on figure 9, the highest of respondents drinking coffee at San Francisco Coffee is Malay, which are $57 \%$ compared to Chinese $17 \%$, follow by $5 \%$ who are Indian and $21 \%$ of the respondents being other race.

As shown in figure 10, 40\% respondents have the highest personal spending monthly on coffee of about RM50 and below, while $28 \%$ respondents spend monthly on coffee with about RM51 to RM80. This is follow by 7\% who spend monthly on coffee of about RM80 to RM100 and other personal spend monthly on coffee of RM100 and above which is related with the race as it has been observed earlier.

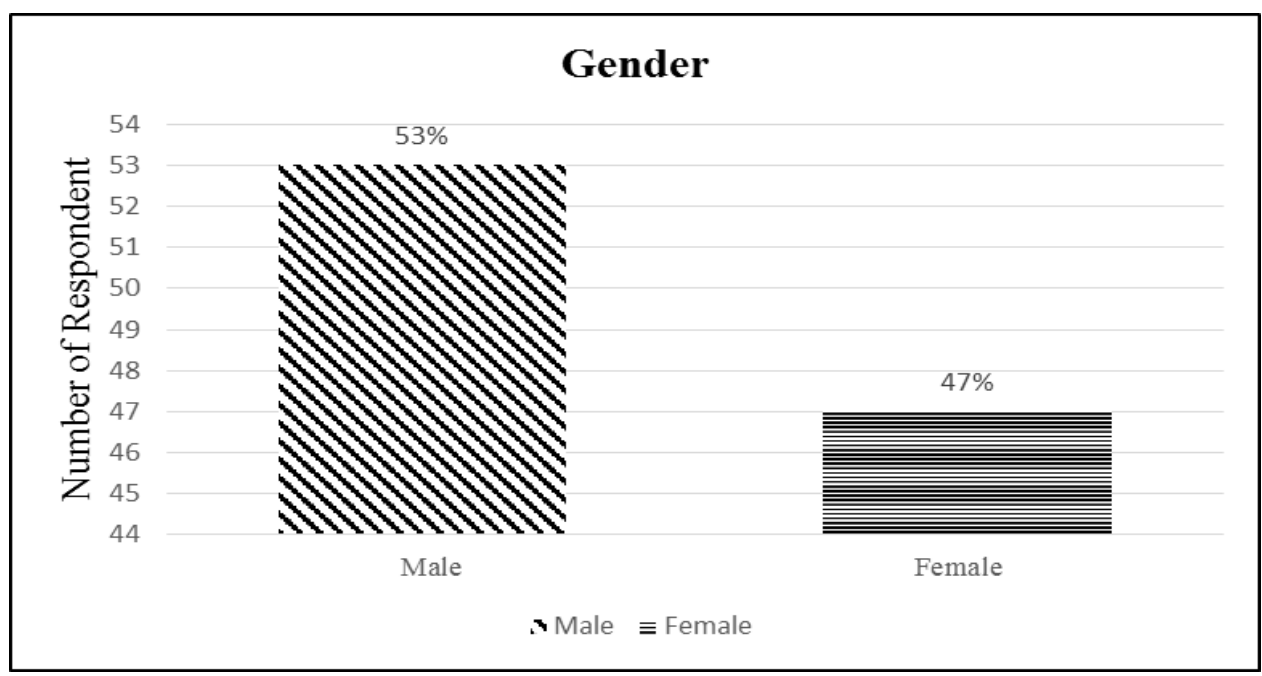

Figure 7: Demographic Information (Gender) 
DOI: https://doi.org/10.47405/mjssh.v5i4.398

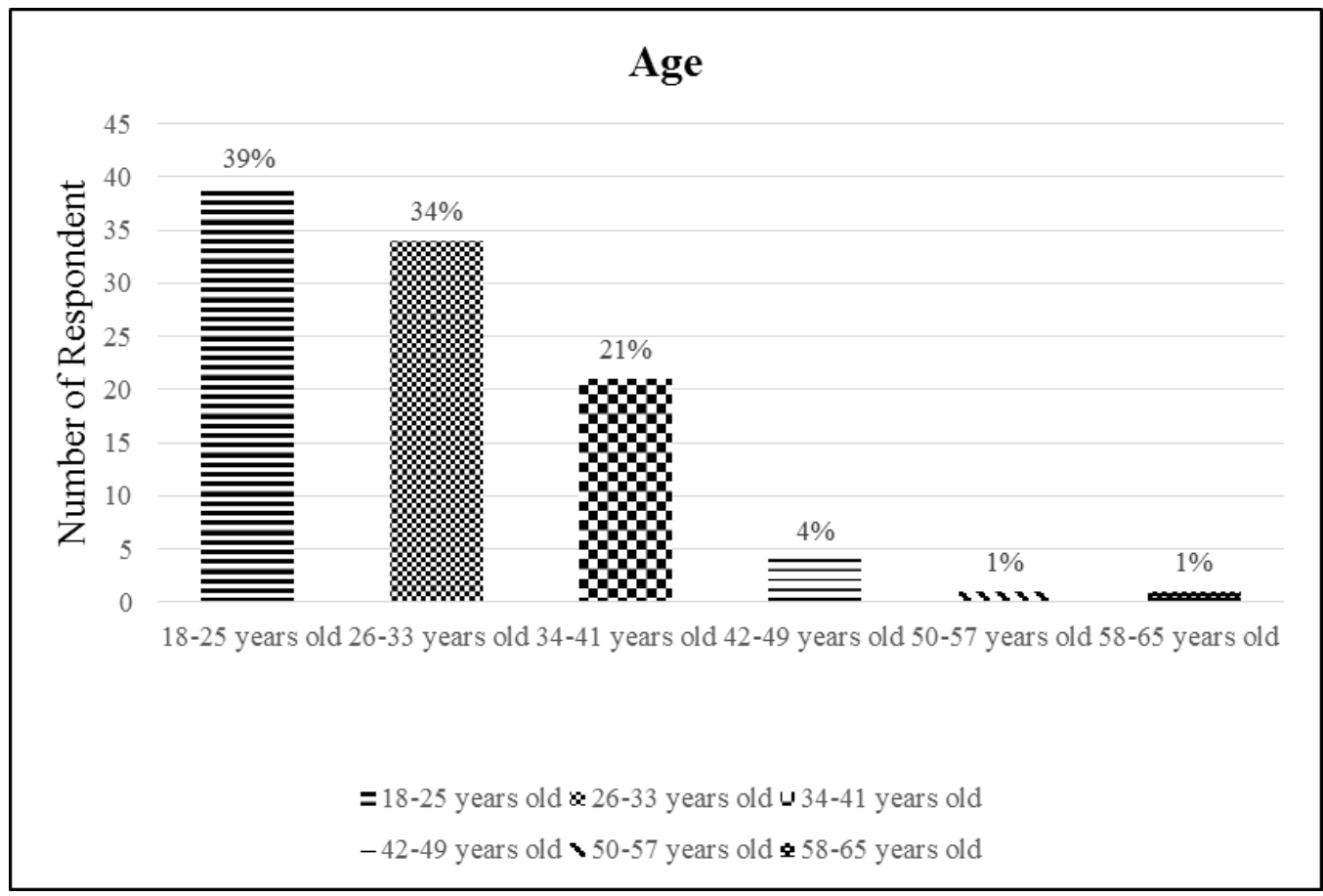

Figure 8: Demographic Information (Age)

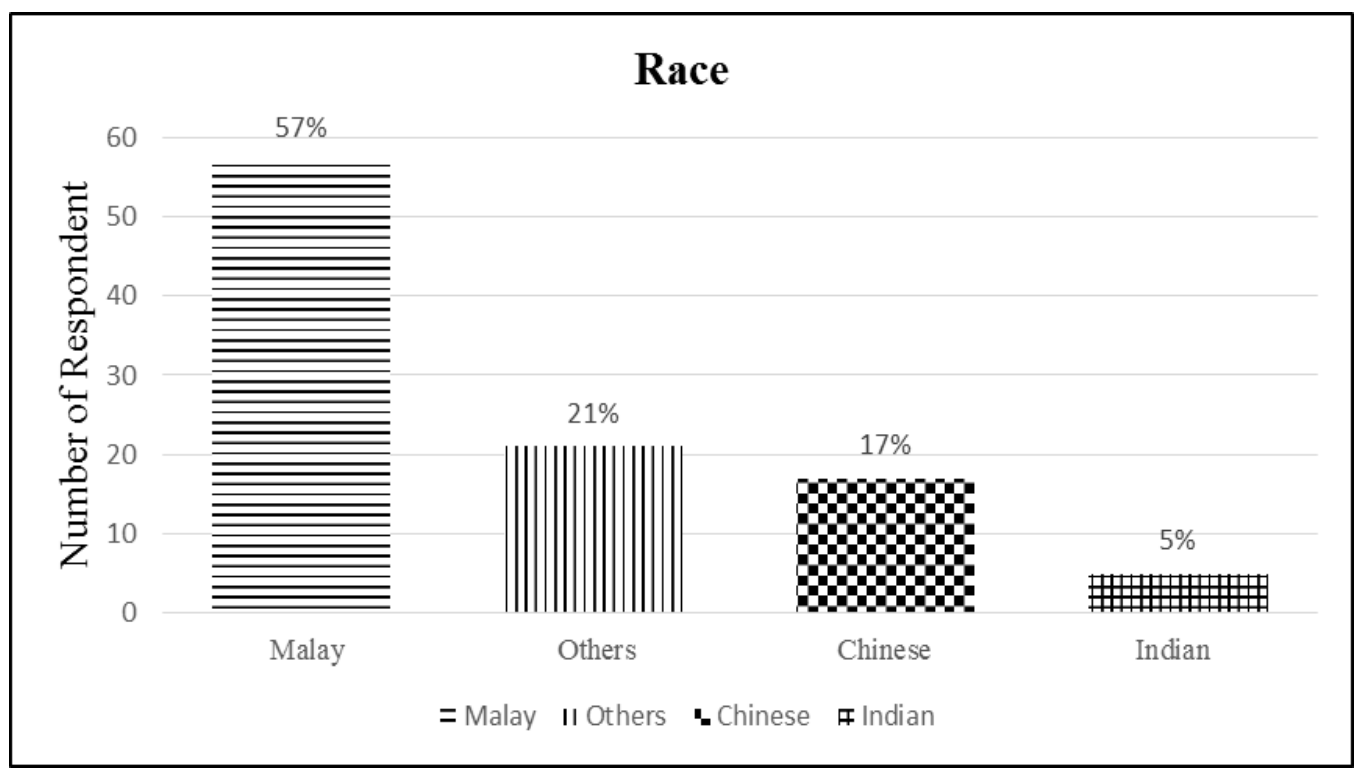

Figure 9: Demographic Information (Race) 


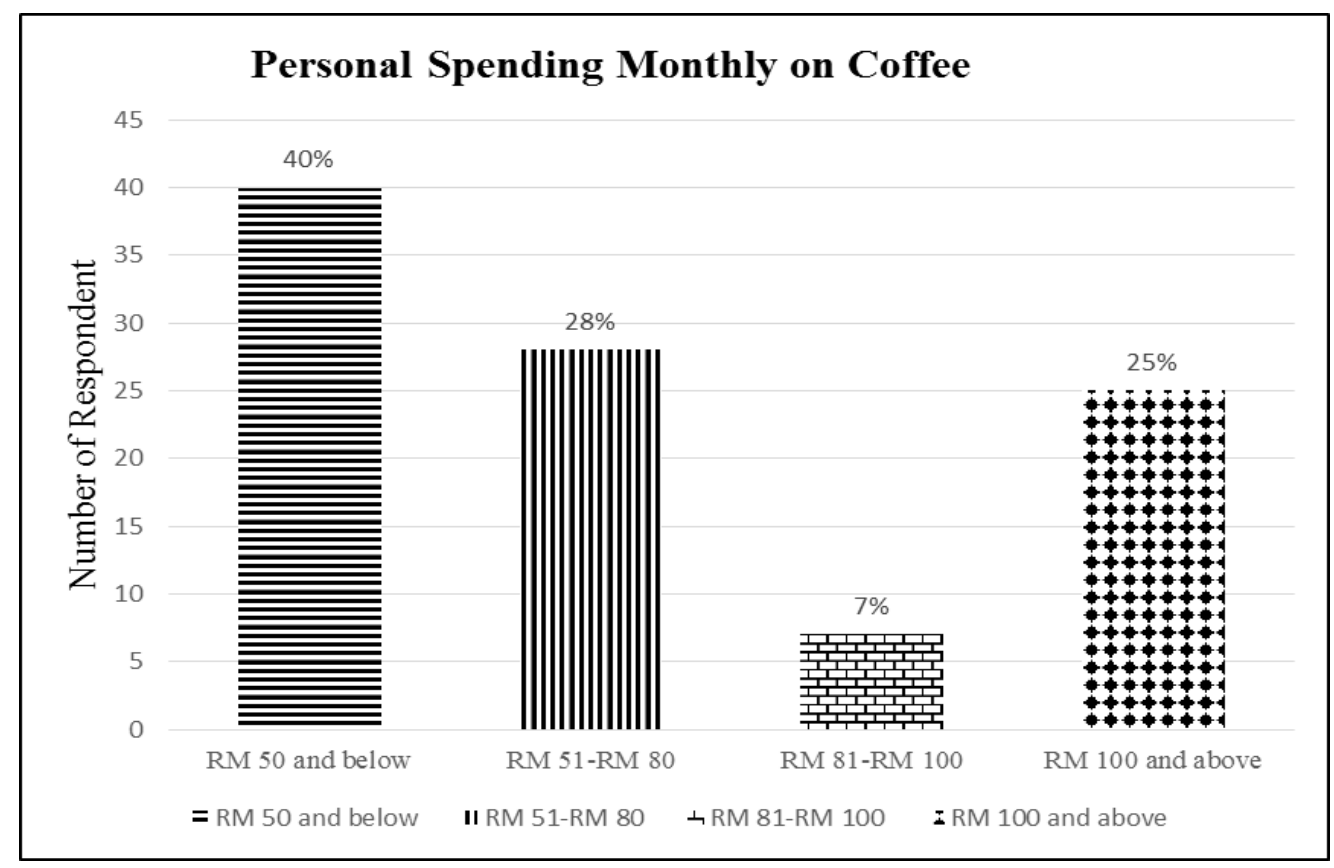

Figure 10: Demographic Information (Personal Spending Monthly on Coffee)

\section{Customer perception on San Francisco Coffee in KL Gateway Mall}

\section{Price}

There are 4 questions in section B of the questionnaire of the present study representing the customer perception on San Francisco Coffee in K1 Gateway Mall. Based on Figure 11, analysis shows that majority of the respondents are $46 \%$ who agreed that the price of the product is the most important factor in making purchase while other $44 \%$ was either agree or disagree with the statement. Only $44 \%$ of the respondents compare prices of other coffee shop before they purchase because they will automatically buy other's coffee shop if the price is lower than San Francisco Coffee shop. More so, some $67 \%$ of the respondents believe that their purchase intention will increase when ever San Francisco Coffee is having a promotion .Besides that, $45 \%$ of the respondents will switch to the other brand providing promotion and discount. This will have resulted to the declining of numbers of San Francisco Coffee shop customers if their competitors, such as Starbucks is having more promotion to attract them. Lastly, it can be seen in general that $53 \%$ of the respondents will purchase San Francisco Coffee if the price is the lowest among their competitors. This is because if San Francisco Coffee decides to level up their price, they will be having the loss of consumer's loyalty as they might be changing to other coffee shop, such as The Coffee Bean \& Tea Leaf since they will have a lower price than this coffee shop.

\section{Service quality}

Based on the questionnaire collected, there are total of 100 respondent. For the first question, and $82 \%$ of them agreed that important of personal service can increase the customer's purchase intention. Also, $87 \%$ of the respondent agreed that the service personnel must always understand all customer needs, While $85 \%$ of the respondents agreed that customer purchase intention on San Francisco Coffee will increase, if they properly allocated the time management when the service is provided. Furthermore, $84 \%$ of respondent agreed that the customer interest as priority can increase number of sales, while $84 \%$ of the respondent agreed that customer with personalized service can increase customer intention by offering various type of foods and beverages. For the last question, there are $87 \%$ of respondents who strongly agreed that the sales of San Francisco Coffee can increase, if they provide reliable services. 


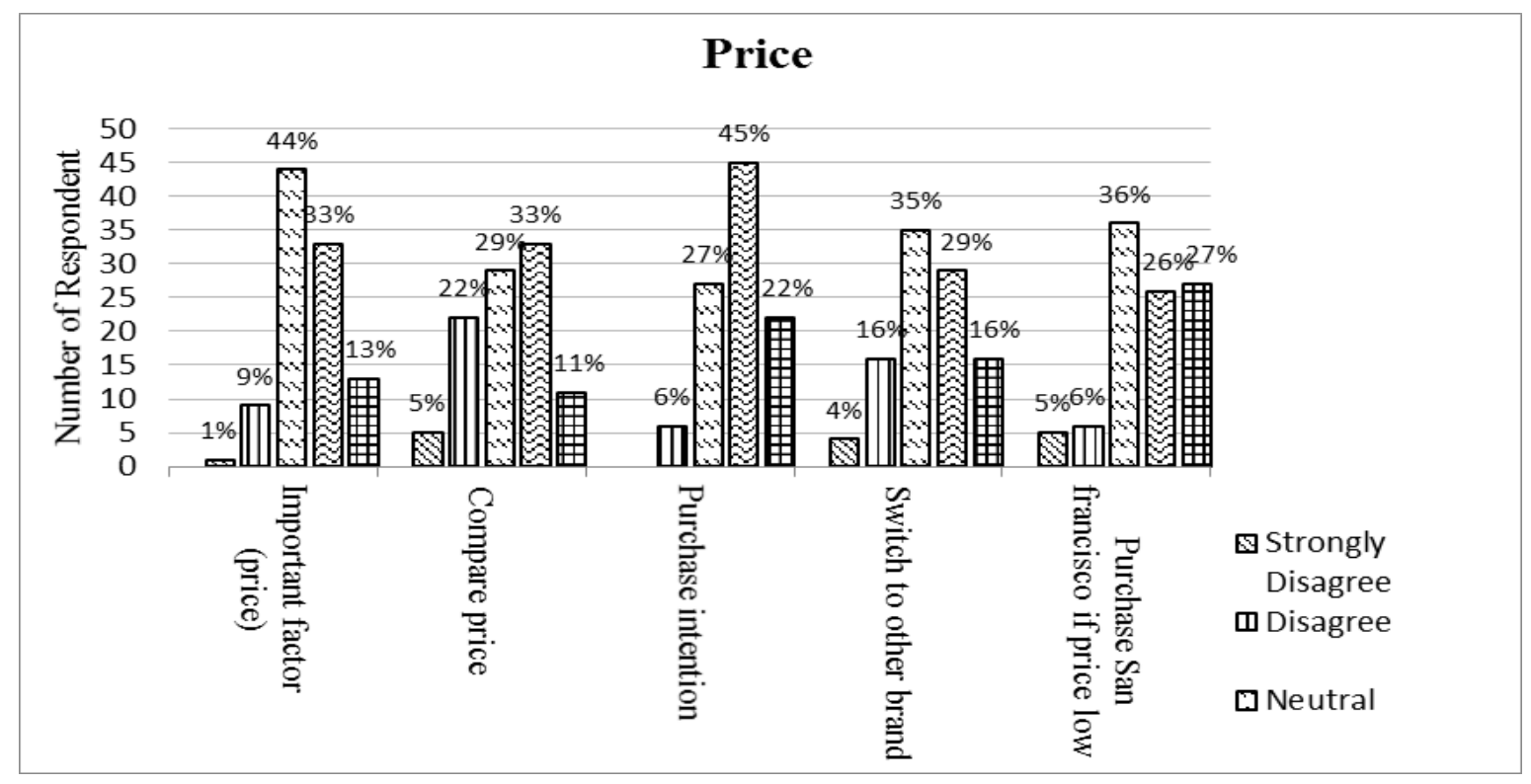

Figure 11: Customer Perception on San Francisco Coffee in KL Gateway Mall (Price)

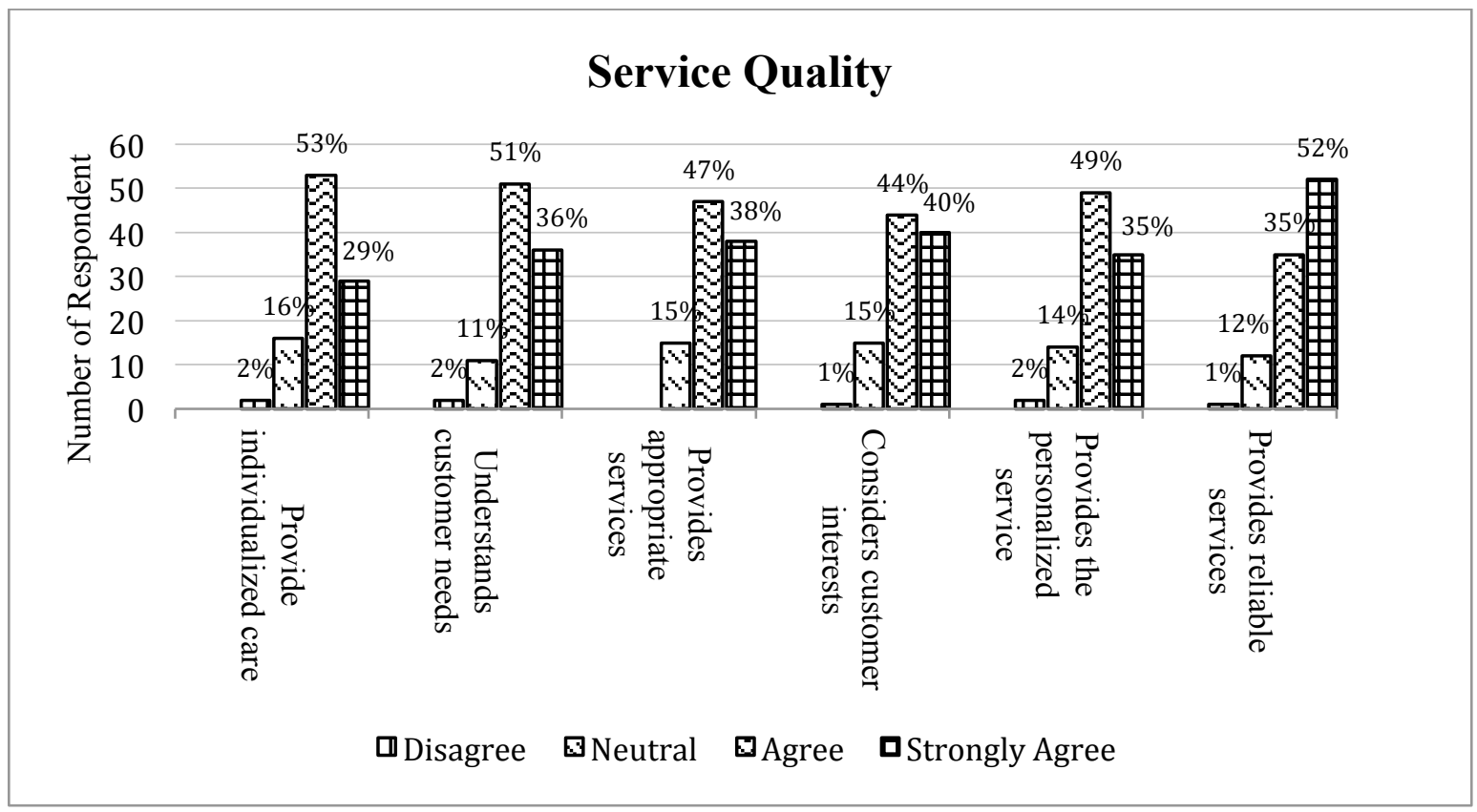

Figure 12: Customer Perception on San Francisco Coffee in KL Gateway Mall (Service Quality)

\section{Brand image}

Based on the research outcome, brand image is significant towards purchase intention as the result show that over $76 \%$ of 100 respondents will switch to other brand if it provides good quality products, due to the customer emphasis to the quality of the products. Besides that, $67 \%$ respondents said that they will purchase those brands which have a good reputation in the market. As such, the San Francisco should standardized and remain the good reputation in the market to attract their customers. Also, $52 \%$ of almost half of the respondents said that they will not buy if the brand does not go well. This is because a product that have a well-known brand name will increase the consumer purchase intention. For instance, positive brand image will creates purchase intention and negative image will creates no purchase intention. Furthermore, $69 \%$ responded that brand reputation influence them to 
purchase the product. According to previous researcher, if a product is familiar to consumer, they will have more confidence to buy it. This is because a brand with good image will makes consumers feel safe and trustable to consume it, thus it would help to enhance the consumer's purchase intention. In short, the brand image is a very important aspect towards purchase intention.

\section{Cleanliness}

Based on the present research outcome, $76 \%$ of respondents mostly agreed with their hairstyle, hair pulled back and good haircut. It shows that the customer are satisfy and agreed with their hairstyle when in duty. Also, $80 \%$ of the respondents agreed that the uniform are neat and tidy. It's definitely have a good attire and only $20 \%$ do not satisfied with their uniform. On the other hand, $79 \%$ shows that they agreed with the cleanliness that refers to nails and hands. While $18 \%$ were neutral of agreed and disagreed. Lastly, the highest percentage of $30 \%$ of the respondents stated that the customer are neutral towards the accessories used by the worker in the San Francisco Coffee shop. Generally, the customer were satisfy with the cleanliness.

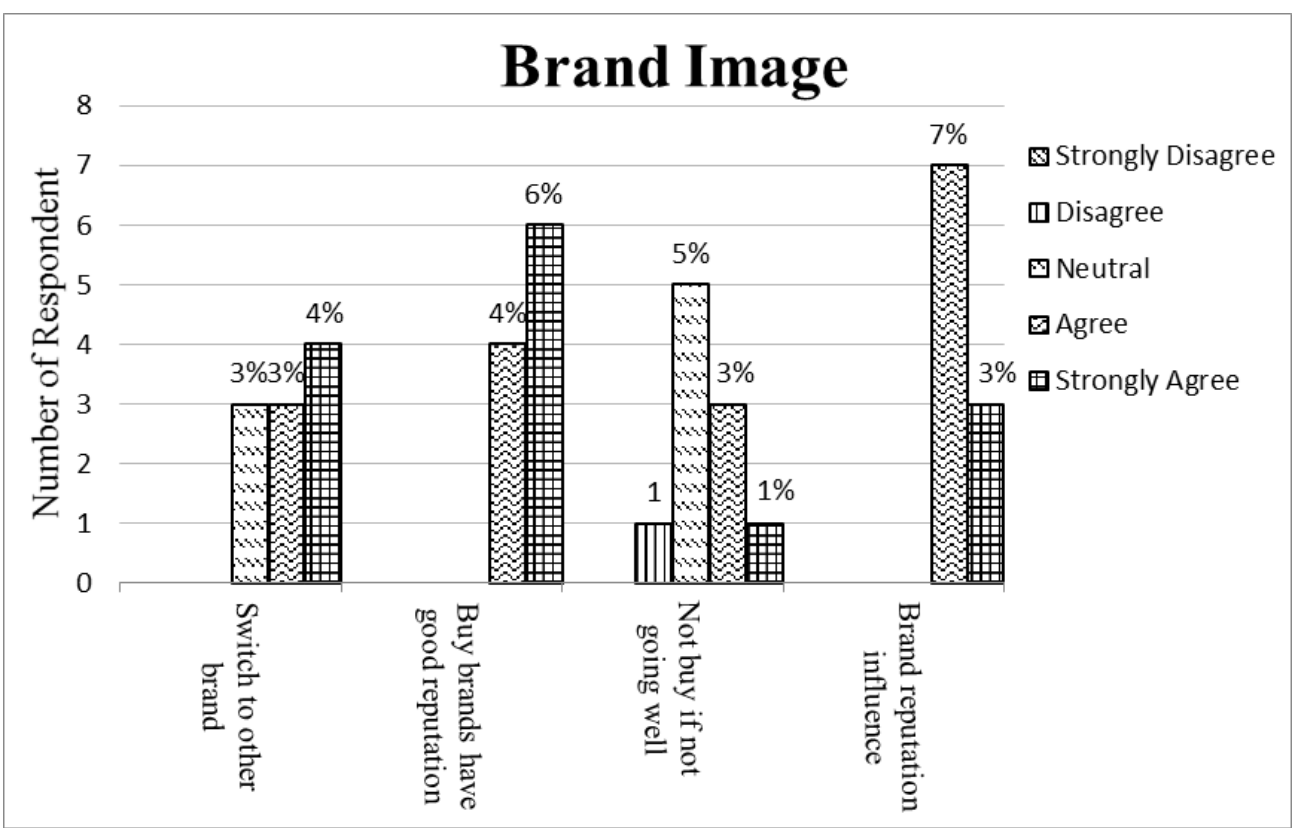

Figure 13: Customer Perception on San Francisco Coffee in KL Gateway Mall (Brand Image)

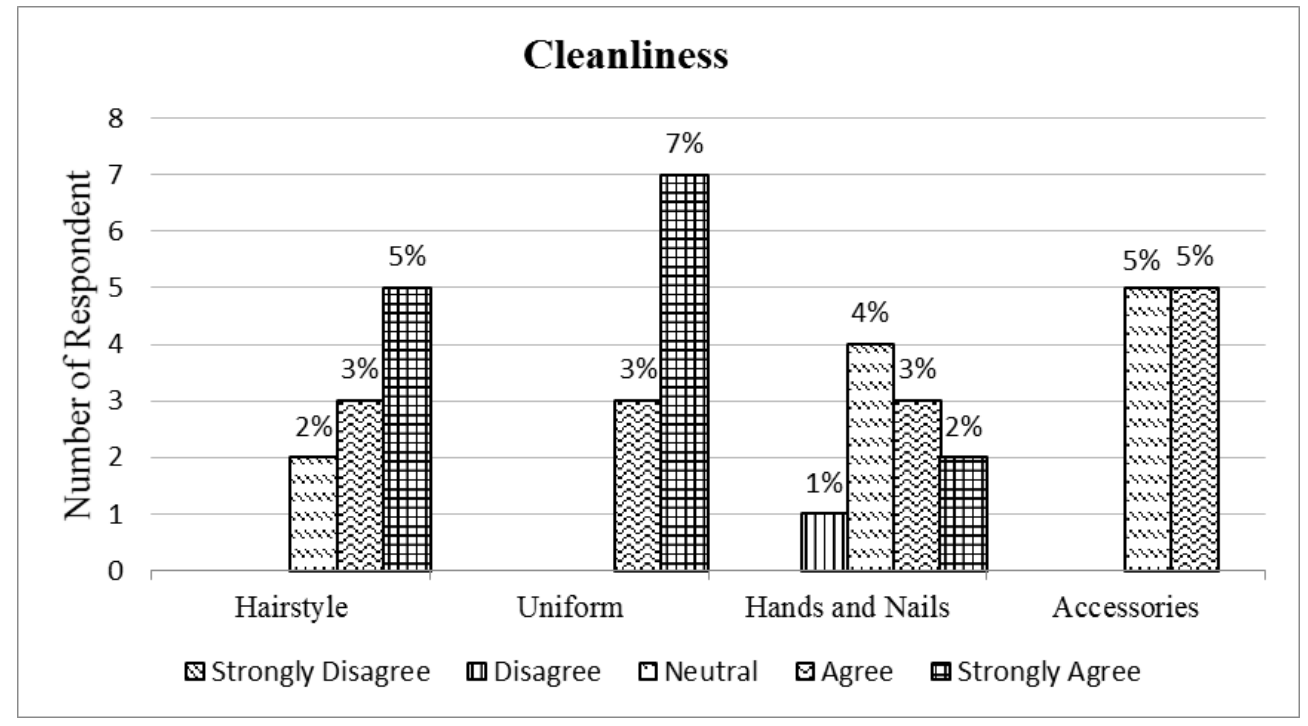

Figure 14: Customer perception on San Francisco Coffee in KL Gateway Mall (Cleanliness) 


\section{Price}

San Francisco Coffee should standardized and maintain their current price. They also should make sure the price is similar with the competitors, in order for their customers not to switch to other brands.

\section{Service quality}

The San Francisco Coffee customers emphasized more on the importance of the product quality. Therefore, they have to provide the service that meet the customers expectation and gain customer trust towards their product.

\section{Brand image}

Brand reputation influence customers to buy their product, thus San Francisco Coffee should sustain the good reputation in the market.

\section{Cleanliness}

San Francisco Coffee should provide a hygienic environment for their customers so that the customers will enjoy their time in the coffee shop as they need to prioritize their health issues.

\section{Implication of the Study}

This research help San Francisco improve their company performance, increase revenue and build a strong brand image among coffee industry, as drinking coffee has become the culture of Malaysians. The present research is carried out to discover the factor driving customer perception towards San Francisco in order to better maximize their profit. In this research, it is learned that independent variables (price, service quality, brand image and cleanliness) of shop are important to satisfy the level of satisfaction toward consumers. This is because when customers are satisfy with a particular brand, then the purchase intention will increase and the customers will go and buy the particular brand.

\section{Comparison of findings between San Fransisco Coffee and Starbucks}

From the aspect of price, if San Francisco did not do any price promotion towards their product, their customers may run to others coffee shop. However, from the aspect of service quality, the results proved that the service quality will increase the buying intention when San Francisco Coffee provid good service towards the consumers. Brand image is also very important to San Francisco Coffee because if the brand image did not go well, the consumers may switch to other brand. In term of cleanliness, most of the respondents agreed with the workers' hairstyle, uniform and their personal hygiene.

With respect to price towards the previuos studies, if customers knows about the product, they will still buying such particular coffee brand regardless of the price. According to Cronin and Taylor (1992), who proved that the quality of service was negligible towards the customer buying intention. The authors emphasized that satisfaction will be considered when customers are able to purchase a particular product. For example, Starbucks do a reminder advertisement for their product because advertisement will help in increasing their sales. In terms of cleanliness, this is important for customers' satisfaction level and future revisit decision. Hence, operators or the restaurant must pay attention to a wide range of goods to make sure the highest level of cleanliness in restaurants is observed. 


\section{Limitations of the Study}

There are some limitations, however should be acknowledge. The limitation as follows:

\section{i) Comprehending the questionnaire}

Foreigners have some trouble in comprehending the questionnaire. This is because the questionnaire are provided fully in english and some of the foreigners from China and Italy can not understand the question, thus hard to collect data.

\section{ii) Geographical biased}

Distribution in San Francisco KL Gateway Mall only and not for the others branches, as the survey was succesfully completed at the given place.

\section{iii) Customer's behaviour will change time to time}

Consumers and the environment will change in the future as the interest that they have stated before might change in the future. However, the present study successfully collect the customers current behaviour towards San Fransisco Coffee.

\section{Ethical Consideration}

When conducting the survey in San Francisco KL Gateway Mall, there were some ethical consideration that needed to be follow as the way to encourage people involve in the current survey. During the conduct of the survey, an interuption of the customer might occur in customer's important discussion or meeting. Furthermore, as a way of approaching people to respond to the survey, as they cannot be force to answer it, thus every action in the survey must be in the voluntarily act. By doing the survey, the researchers need to talk to them in a high manner so that the respondents will feel comfortable. Lastly, as a proper way to conduct the survey, there was need to wear an appropriate attire and the student card was compulsory for identification when performing the survey. This is because some of the respondent might be doubtful if the resrachers do not have the student card while conducting the survey.

\section{Further Studies}

There are several recommendations for for future research form the current study. First and foremost, future researchers are encouraged to develop a larger sample size in order to enhance the accuracy and reliability. As such, the number of sample can be enlarged to 300 respondents instead of 100 respondents. Besides that, future researchers are encouraged to retain the consistency among the races and age range by distributing the questionnaire to the targeted people. Also, future researchers are suggested to explain the elements to the respondents if they found it a bit confused in answering the questions. It is also suggested for future researchers to request for the approval of the upper management earlier so that the coffee shop can provide any benefits to them, such as vouchers or gifts to conduct an efficient survey. Additionally, future researchers are encouraged to use other variables, such as taste, ambiance and environment factors that might affect the customer's perception towards San Francisco Coffee. Last but not the least, future researchers are suggested to adopt questionnaire carefully because every individuals has different perceptions towards the independent variables. Therefore, future researchers have to make sure that the questions will not be tricky and hard to understand. 


\section{Conclusion}

In conducting this survey, the questionnaire were distribute among the customer in San Francisco Coffee of KL Gateway mall only. AS such, a collaboration was made with the San Francisco in conducting this survey, during which permission was given to collect data for 2 days. After the approval to conduct the survey in their premise, the San Francisco provided 100 voucher to ensure that the customer does not feel disturbed and for the survey to be conducted in an ethical manner. The voucher help to collect the data efficiently from the customer, as most of the customer are willing to answer the questionnaire because of the voucher. The voucher were given to the customer that contributed their time to answer the questionnaire. At the same time, San Francisco could promote their product and increase sales. The use of the voucher allow the respondent to have two option, which are having a black coffee for free or buying any products of San Francisco that could save up to RM 6.60.

The objectives to study the relationship between price, service quality, brand image and cleanliness on customer perception toward San Francisco Coffee have been fulfilled throughout the present research. There are three factors (price, service quality, and brand image) which shows positive relationship but the cleanliness show no positive relationship on customer perception towards San Francisco Coffee. Hence, some recommendations have been provided as guidance for future researchers to conduct similar research.

\section{References}

Amir Azahari Zainol, Siti Nor Izzaty Norashikin \& Zurinawati Mohi. (2015). Student Satisfaction towards Caffe Giunto. Proceedings of the Innovation and Best Practices in Hospitality and Tourism Research - Jamal et al (eds) C 2016 Taylor \& Francis Group, London, ISBN 978-1138-02932-3.

Amir Mahmud, Kamaruzaman Jusoff \& St. Hadijah. (2013). The Effects of Service Quality and Price on Satisfaction and Loyalty of Customer of Commercial Flight Service Industry. World Applied Sciences Journal, 23(3), 354-357.

Azdel Abdul Aziz. (2018). The Relationship between Brand Personality and Customer Satisfaction in Local Premium Coffee Shop. Journal Of Techinical And Vocational Education, 1, 87-96. Retrieved March 15, 2019.

Hashed Ahmad, Hasnizam Shaari, \& Salniza Md. Salleh. (2017). The influence of brand image and brand personality on brand loyalty, mediating by brand trust: An Empirical Study. Jurnal pengurusan, 50, 72-79.

Jazira Anuar, Mohd Azuan Mohd Alias, \& Tajulurrus Mohamad. (2017). University student's perception on the fast food industry service quality in Terengganu. Journal of Tourism,9(2), $551-554$

Lim, E.C., Ooi, C.Y., \& Tan, M.W. (2017). Customer Loyalty: A Study on Newly Opened Cafes and Restaurants in Penang. Journal of Foodservice Business Research, 20:5, 525-541, DOI:10.1080/15378020.2016.1222743.

Mini Sheth, Ashima Gupta \& Tejal Ambegaonkar. (2011). Handlers' hygiene practices in small restaurants of Vadodara. Nutrition \& Food Science, 41(6), 387-389.

Mohd Salehuddin, Mohd Zahari, Nuraliah Mansur, Mohd Hafiz Hanafiah, Salleh Moh Radzi \& Rahmat Hashim. (2010). Restaurant Brand Image Attributions, Customer Preferences and Purchase Decision: Evidence from Malaysia. Scientia Journals, 1(1), 32-34.

N. Krishna Naik., Swapna Bhargavi Gantasala., \& Gantasala V. Prabhakar. (2010). Service Quality (Servqual) and its Effect on Customer Satisfaction in Retailing. European Journal of Social Sciences, 16(2), 240-243.

Noorliza \& Fariza. (2018). Service Quality Measurement in Kopitiam Seberang Jaya, Pulau Pinang. Journal of Applied Environmental and Biological Sciences, 5(6S), 100. Retrieved April 13, 2019.

Prabha Ramseook-Munhurrun. (2012). Perceived Service Quality in Restaurant Services: Evidence From Mauritius. International Journal of Management and Marketing Research, 5(3), 2-5. 
Malaysian Journal of Social Sciences and Humanities (MJSSH), Volume 5, Issue 4, (page 116 - 132), 2020

DOI: https://doi.org/10.47405/mjssh.v5i4.398

Yousef Keshavarz, Farid Bakhtazma \& Dariyoush Jamshidi. (2016). The Influence of Service Quality on Restaurants' Customer Loyalty. Arabian Journal of Business and Management Review, $6(4), 2-5$. 